ForUM: TIMES OF THE Event

3.

\title{
BEYOND REPRESENTATION: PICTORIAL TEMPORALITY AND THE RELATIONAL TIME OF THE EVENT
}

\author{
BRITTA HOCHKIRCHEN
}

\begin{abstract}
Pictures are often connected with the mediation of the event but, paradoxically, not with temporality as such. Although there are several existing approaches that focus on the interplay between the event and its literary representation, the relation between pictorial time and the temporal constitution of the event remains unexplored. The field of image theory has offered insights into the multiple dimensions of the picture's temporality. It has shown that the picture's temporality concerns not only the depicted event but also the picture's immanent modes of producing different temporalities within one pictorial plane. The picture thus not only makes visible but also generates multilayered times of the event. This article brings together insights from image theory and from theories of historical times to demonstrate the relationship between the times of the event and the inner logic of the picture. In order to identify the various qualities of the picture that structure the times of the event, this article uses the case study of Reinhart Koselleck's practical and theoretical work with pictures. This article reads Koselleck's approaches to pictures alongside new insights concerning the relationality of time to the event and the picture. By exploring the picture's agency with regards to the politics of time, this article lays bare the picture's potential to structure the times of the event.
\end{abstract}

Keywords: event, time, pictorial temporality, Koselleck, pictorial politics, mediatization

Today it is somewhat common to suggest that pictures play important parts in (re)constructing and mediating events. But although pictures are often connected with the representation of historical events, their inherent temporality is rarely studied. Scholarship on pictures of historical events such as wars, catastrophes, or revolutions has shown how pictures contribute to the construction of events by creating and structuring their visibility. ${ }^{1}$

The simultaneity of events and their pictorial mediation is often emphasized in scholarship on art and media history. ${ }^{2}$ Recent studies (especially ones on the socalled media event) have shown how pictorial media temporalize - for instance, through synchronization - the reception of an event by uncoupling the event

1. See, for instance, Frank Bösch, "Ereignisse, Performanz und Medien in historischer Perspektive," in Medialisierte Ereignisse: Performanz, Inszenierung und Medien seit dem 18. Jahrhundert, ed. Frank Bösch and Patrick Schmidt (Frankfurt: Campus, 2010), 7-30, especially 15.

2. For an example of such scholarship, see Dietrich Erben, "Das Ereignis und seine Bilder: Zur medialen Gegenwart des Terroranschlags auf das World Trade Center in New York," in Bilder machen Geschichte: Historische Ereignisse im Gedächtnis der Kunst, ed. Uwe Fleckner (Berlin: De Gruyter, 2014), 447-62, especially 449. 
from its original temporal context. ${ }^{3}$ These studies have stressed the picture's special ability to link different spaces and, by association, conceptions of time. ${ }^{4}$ Still, these studies have tended to understand time and space as preexisting and therefore external to the pictorial mediatization of events. Accordingly, they have interpreted pictures as points at which different times and spaces intersect. But what gets lost in such an analysis is the fact, as I argue here, that the temporality of the picture is itself multilayered.

Although there are several existing scholarly works that focus on the interplay between the event and the temporal structure of its literary and historical representation, the relationship between pictorial time and the temporal constitution of the event remains unexplored. ${ }^{5}$ The reason for this is the fact that the picture is conventionally linked to space rather than to time. ${ }^{6}$ This idea goes back to Gotthold Ephraim Lessing's famous treatise "Laokoon oder über die Grenzen der Malerei und Poesie" ("Laocoon: An Essay on the Limits of Painting and Poetry"), which was originally published in 1766 . Here, Lessing differentiated between the picture (which he linked with space because he claimed it could only depict a single moment) and poetry (which he linked to time because he claimed it could represent a succession of moments). ${ }^{7}$ Lessing thus denied the possibility that temporality was a quality of the picture itself. This understanding of the picture as recording a specific moment in time has, to this day, remained dominant.

In recent decades, however, there has been a determined effort in Germanspeaking art history to develop a new theory of the image (this approach is called Bildtheorie) in order to scrutinize the picture's characteristics systematically and to examine the logic inherent in this medium. This approach-which generally builds on Gottfried Boehm's phenomenological and hermeneutic insights adopts a broader conceptualization of the picture, one that exceeds (normative)

3. See, for instance, Frank Bösch, Zeitenwende 1979: Als die Welt von heute begann (München: Beck, 2019), 13; Media Events in a Global Age, ed. Nick Couldry, Andreas Hepp, and Friedrich Krotz (London: Routledge, 2010); Daniel Dayan and Elihu Katz, Media Events: The Live Broadcasting of History (Cambridge, MA: Harvard University Press, 1992).

4. See Bösch, "Ereignisse, Performanz und Medien," 9.

5. Examples of scholarship that focuses on the interplay between the event and the temporal structure of its literary and historical representation include Reinhart Koselleck, "Representation, Event, and Structure," in Futures Past: On the Semantics of Historical Time, transl. Keith Tribe (New York: Columbia University Press, 2004), 105-14; Peter Burke, "History of Events and the Revival of Narrative," in New Perspectives on Historical Writing, ed. Peter Burke (Cambridge, UK: Polity, 1991), 233-48; Geschichte - Ereignis und Erzählung, ed. Reinhart Koselleck and WolfDieter Stempel (Munich: Fink, 1973); Hayden White, Metahistory: The Historical Imagination in Nineteenth-Century Europe (Baltimore: Johns Hopkins University Press, 1973).

6. For more on this assumption, see Gottfried Boehm, "Bild und Zeit," in Das Phänomen Zeit in Kunst und Wissenschaft, ed. Hannelore Paflik (Weinheim: VCH, Acta Humaniora, 1987), 1-24, especially 6.

7. Gotthold Ephraim Lessing, "Laokoon oder über die Grenzen der Malerei und Poesie," in Werke und Briefe, vol. 5/2, Werke 1766-1796, ed. Wilfried Barner (Frankfurt: Deutscher Klassiker, 1990), 11-206, especially 116. See also Johannes Grave, "Der Akt des Bildbetrachtens: Überlegungen zur rezeptionsästhetischen Temporalität des Bildes," in Zeit der Darstellung: Ästhetische Eigenzeiten in Kunst, Literatur und Wissenschaft, ed. Michael Gamper and Helmut Hühn (Hannover: Wehrhahn, 2014), 51-72, especially 51; Dieter Mersch, “Ästhetischer Augenblick und Gedächtnis der Kunst: Überlegungen zum Verhältnis von Zeit und Bild," in Die Medien der Künste: Beiträge zur Theorie des Darstellens, ed. Dieter Mersch (München: Fink, 2003), 151-76. 
definitions of art and includes everyday images (for example, press photographs or simple snapshots) in discussions about the logic and potential of the picture. Such inquiries into the characteristics of pictures also bring their intrinsic temporal logic into focus in new ways. ${ }^{8}$ The argument that pictures are entangled with temporality on different levels - including in terms of their time of production, materiality, depicted motifs, or reception - serves as a starting point for explorations into the temporality of the picture. ${ }^{9}$ However, debates about temporality in image studies do not often reference the temporal categories and time theories developed in the theory of history, ${ }^{10}$ even with regard to the temporality of the pictorial event. ${ }^{11}$

I address this forum's theme by analyzing the times of the event in relation to the temporal logic of the picture. Doing so, I argue for the picture's potential to structure the temporality of the event. The basic assumption that the category of the event is characterized by its relational temporal character serves as the guiding principle for my analysis of pictures. ${ }^{12}$ The event's inherent temporal difference-and therefore the inherent relation of distinct times in the event-becomes particularly visible and epistemically tangible in pictorial mediatizations of events. Thus, however, it is important to understand the picture and the concept of the event as configurations rather than as homogeneous units.

In what follows, I not only highlight structural similarities between the concept of the event and the picture but also demonstrate the possibility of using the picture analytically for historical research on the event and its mediatization. To clarify this, my argument will proceed in two steps. In the first section, I employ an image-theoretical perspective to lay bare the ways that time operates in (and in relation to) pictures. Doing so, I show how we might use pictorial temporality to understand the temporal relations that characterize the event. Pictures not only represent events but also structure their very temporality, in turn contributing to the pluritemporality of the event. In the second section, I use a case study to delve further into these issues. In particular, I discuss how Koselleck, one of the

8. For examples of this focus, see Zeiten der Form - Formen der Zeit, ed. Michael Gamper, Eva Geulen, Johannes Grave, Andreas Langenohl, Ralf Simon, and Sabine Zubarik (Hannover: Wehrhahn, 2016); Grave, "Der Akt des Bildbetrachtens."

9. Examples of this include Heinrich Theissing, Die Zeit im Bild (Darmstadt: Wissenschaftliche Buchgessellschaft, 1987); Götz Pochat, Bild - Zeit: Zeitgestalt und Erzählstruktur in der bildenden Kunst von den Anfängen bis zur frühen Neuzeit (Wien: Böhlau, 1996); Alexander Nagel and Christopher S. Wood, Anachronic Renaissance (New York: Zone Books, 2010), especially 9.

10 . For examples of works that reference the temporal categories and time theories within the theory of history, see Zoltán Boldizsár Simon, History in Times of Unprecedented Change: A Theory for the 21st Century (London: Bloomsbury Academic, 2019); François Hartog, Regimes of Historicity: Presentism and Experiences of Time, transl. Saskia Brown (New York: Columbia University Press, 2015); Aleida Assmann, Ist die Zeit aus den Fugen? Aufstieg und Fall des Zeitregimes der Moderne (München: Hanser, 2013); Breaking up Time: Negotiating the Borders between Present, Past and Future, ed. Chris Lorenz and Berber Bevernage (Göttingen: Vandenhoeck \& Ruprecht, 2013).

11. For an exception, see Johannes Grave, "Pictorial Temporality and the Times of History: On Seeing Images and Experiencing Time," in Rethinking Historical Time: New Approaches to Presentism, ed. Marek Tamm and Laurent Olivier (London: Bloomsbury, 2019), 117-30.

12. For more on the question of the performed and created temporal distinctions among past, present, and future (but without a focus on the category of the event), see Berber Bevernage and Chris Lorenz, "Breaking Up Time - Negotiating the Borders between Present, Past and Future," in Lorenz and Bevernage, Breaking Up Time, 7-35, especially 9. 
most prominent theorists of historical times, interlinked his thinking about the historical category of the event with his engagement in pictorial practices that emphasized the different temporalities within pictures. In this manner, I argue, Koselleck created his own pictorial access to the event and its pluritemporality, which in turn played a central role in his photography.

\section{PICTORIAL TEMPORALITY}

The most common understanding of the relationship between pictures and time is that pictures isolate moments, the before and after of which can only be imagined by the viewer. Time is assumed to be an external container to which the picture refers by either representing or creating a specific point in time. In contrast, recent research in the field of image theory has suggested that temporality is not external to the picture or something that precedes it; instead, this research has recognized that the picture itself has a temporal quality. ${ }^{13}$ However, this pictorial temporality is not homogeneous but is instead characterized by a hybrid plurality that often includes conflicting and contrasting aspects. A basic premise for understanding pictorial temporality is recognizing that the picture is not a homogeneous, onedimensional artifact that can only be understood in its representational (objective)

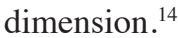

When, in a debate with W. J. T. Mitchell during the 1990s, the German art historian and philosopher Gottfried Boehm announced the "iconic turn," his focus was on emphasizing the picture's potential to generate knowledge. ${ }^{15}$ Challenging the opinion, which had prevailed since the linguistic turn of the 1970s, that language alone is connected to logos, Boehm emphasized that pictures - and not just language - produce meaning and knowledge. More specifically, his central point was that pictures create meaning and thus also understandings of the world and history but that they do so in different ways than language does. His arguments were based on scholarship that was critical of the idea that language alone produces knowledge, including works by Edmund Husserl, Martin Heidegger, and Ludwig Wittgenstein. ${ }^{16}$ Boehm's guiding principle for conducting this analysis was the importance of reflecting on one's own knowledge conditions. ${ }^{17}$ This guiding principle has also informed this forum's approaches to the event and to the historical conditions of knowledge. Through his hermeneutic investigations

13. See, for example Grave, "Der Akt des Bildbetrachtens"; Gamper, Geulen, Grave, Langenohl, Simon, and Zubarik, Zeiten der Form - Formen der Zeit; Vision in Motion: Streams of Sensation and Configurations of Time, ed. Michael F. Zimmermann (Zürich: Diaphanes, 2016); Erscheinung und Ereignis. Zur Zeitlichkeit des Bildes, ed. Emmanuel Alloa (München: Fink, 2013); Arno Schubbach, “Zur Darstellung von Zeit und die Zeit der Darstellung," Studia philosophica 69 (2010), 95-119.

14. For more on this, see Gottfried Boehm, "Die Sichtbarkeit der Zeit und die Logik des Bildes," in Die Sichtbarkeit der Zeit: Studien zum Bild in der Moderne, ed. Ralph Ubl (Paderborn: Fink, 2017), 273-88, especially 279.

15. Gottfried Boehm, "Die Wiederkehr der Bilder," in Was ist ein Bild? ed. Gottfried Boehm (München: Fink, 1994), 11-38, especially 13.

16. For these remarks, see Boehm's correspondence with W. J. T. Mitchell in "Iconic Turn: A Letter," in Bildwissenschaft und Visual Culture, ed. Marius Rimmele, Klaus Sachs-Hombach, and Bernd Stiegler (Bielefeld: Transcript, 2014), 19-29, especially 21.

17. Ibid. 
into how pictures generate meaning, Boehm emphasized that pictures are specifically nonpropositional.

A guiding notion for Boehm's analysis was the idea that pictures possess an "implicit processuality," meaning that the elements of one picture do not stay in a fixed relation to each other but rather their different relations constantly change. ${ }^{18}$ Hence, Boehm focused on the "iconic difference" that constitutes every picture: "Every iconic artifact is organized in the form of a visual, intelligent and deictic, and that means non-linguistic difference." 19 According to Boehm, every picture consists of many different elements that have to be related to one another by the beholder - for instance, viewers might see a figure made of lines, so they see the figure and the line. ${ }^{20}$ Boehm defined pictures through this common "structural element." 21 "Heterogeneous phenomena," he explained, meet or contrast with each other within the unity of the pictorial plane..$^{22}$ Yet Boehm was less concerned with the fact that different figurative motifs (or even symbols or iconographies) appear alongside one another in a single picture. Rather, he focused on tracing distinctions that related to the basic elements of pictoriality, such as differences between the mode of representation and what is represented, between materiality and what is represented, and between what he called "continuous moments" and "discrete moments." ${ }^{23}$ Boehm, here, referred to Edmund Husserl's phenomenology and the distinctions he traced between the subject (Thema) and the horizon (Horizont), which Husserl believed constantly interrelate. ${ }^{24}$ For Boehm, the picture is characterized by the fact that the viewer can always see "one aspect under the conditions of the other." ${ }^{25} \mathrm{He}$ explained: "The continuous ground is constant and it is uninterrupted, whereas the elements that appear before and in contrast to it are always individual and distinguishable. ${ }^{26}$ For this reason, Boehm described the inherent relations of different motifs, symbols, and formal aspects that characterize each picture as its " constant' distinction criterion" ("stehendes" Unterscheidungskriterium) ${ }^{27}$

Boehm attributed the picture's temporality to the inherent "iconic difference," or the coming together of different motifs, aspects, and forms in one pictorial plane. This constant relation of different pictorial elements is, according to Boehm, the condition for the experience of time in pictures. ${ }^{28}$ The different pictorial elements are themselves temporally determined by being continuous or discontinuous: "The relation establishes the reference through which the respective

18. Ibid., 27. Unless otherwise specified, all translations are my own.

19. Gottfried Boehm, "Ikonische Differenz," Rheinsprung 11, 1st ed. (2011), 171, https://rheinsprung11.unibas.ch/fileadmin/documents/Edition_PDF/Ausgabe1/glossar-boehm.pdf.

20. This is also the example Boehm refers to in "Jenseits der Sprache? Anmerkungen zur Logik der Bilder," in Iconic Turn: Die neue Macht der Bilder, ed. Christa Maar and Hubert Burda (Köln: DuMont, 2014), 28-43.

21. Boehm, "Ikonische Differenz," 171.

22. Ibid.

23. Ibid.

24. Ibid., 174. See also Grave, "Der Akt des Bildbetrachtens," 63.

25. Boehm, "Ikonische Differenz," 174.

26. Ibid.

27. Ibid., 173.

28. See Boehm, "Bild und Zeit," 7. 
element is determined in the light of the whole field (and in contrast with other elements)." ${ }^{29}$ Moreover, according to Boehm, the "iconic difference" on which every picture is based - that is, its steady potential of alteration - itself possesses the characteristics of an event. He explained:

We understand the iconic difference as an event in the sense of an oscillation or of a logic of contrast. Pictures open up their space of meaning by enabling the eye to move back and forth in a complex manner, allowing it to swing between simultaneous reaching out (Ausgriff) and successive movement (sukzedierende Bewegung). ${ }^{30}$

Therefore, the picture is neither a "thing" nor a "sum of discrete elements" but is instead received by its beholders as a "form of relationship" (Beziehungsform). ${ }^{31}$

Art historian Max Imdahl had already made a similar argument about pictorial temporality, and Koselleck - to whom I soon turn - read Imdahl's investigations into the temporality of the picture..$^{32}$ Imdahl noted, for instance, that the specifically pictorial temporality of Giotto's Arena Chapel frescoes means that they not only possess the sequential temporal nature that is characteristic of linguistic narration. Like Boehm, Imdahl also understood the picture as a structure of relations that, through the interactions of different pictorial elements, thereby created the picture's temporality. He explained: "This whole of the picture becomes noticeable in every relation of the different or even contradictory, insofar as it indicates the different or contradictory within a dialectically mediated unit and thus makes visible in every relation the picture's simultaneous and tense totality." ${ }^{33}$ Because of its "simultaneous and tense totality," the picture thus contains different temporal elements, which, in relation to each other, also involve specific temporal distinctions.

Boehm's image theory, and particularly his notion of "iconic difference," also shares structural similarities with some recent theorizations of the historical category of the event, and particularly theories that understand the event as a temporal focal point. According to Boehm, the picture (like the event) is characterized by an inherent difference of various temporalities - such as continuity and discontinuity, succession and simultaneity - that relate to each other within one pictorial plane. That is why he described the picture itself as an event. The picture's potential to relate different temporalities within a single unit has already been emphasized by some historical theorists. Walter Benjamin, for instance, explored the possibilities of historical knowledge through his concept of the "dialectical image." ${ }^{34}$ Of course, Benjamin's "dialectical image" is not the same thing as a material picture, but as the art historian Johannes Grave pointed out, Benjamin's

29. Ibid., 10 .

30. Boehm, "Ikonische Differenz," 175. Based on this understanding, Boehm repeatedly described "the image as an event" ("Ikonische Differenz," 171).

31. Boehm, "Bild und Zeit," 9.

32. For more on Koselleck's reception of Imdahl's "Ikonik," see Adriana Markantonatos, "Absatteln der 'Sattelzeit'? Über Reinhart Koselleck, Werner Hofmann und eine kleine kunstgeschichtliche Geschichte der Geschichtlichen Grundbegriffe," Forum Interdisziplinäre Begriffsgeschichte 7, no. 1 (2018), 79-84, especially 79.

33. Max Imdahl, Giotto, Arenafresken: Ikonographie, Ikonologie, Ikonik (München: Fink, 1980), 108.

34. Grave, "Pictorial Temporality and the Times of History," 117-18. 
theory of history also emphasized that different times come together and interact in the "dialectical image." 35 Benjamin wrote:

It is not that what is past casts its light on what is present, or what is present its light on what is past; rather, image is that wherein what has been comes together in a flash with the now to form a constellation. In other words: image is dialectics at a standstill. For while the relation of the present to the past is purely temporal, the relation of what-has-been to the now is dialectical: not temporal in nature but figural (bildlich). ${ }^{36}$

Benjamin understood his dialectical image as a relation of different times, such as the past and the present. The concept thus undermines linear understandings of time by emphasizing that different times all come together and interact in the image. Such a relational understanding of time invests the category of the event with new epistemological value, since it offers a way to understand the event as a unit that makes legible the specific relation of different times. This specific relation turns out to be historically different in each case. The picture, which also functions as a unit wherein multiple times come together and interact, offers one way to investigate the different temporal relations in the event.

By referring to pictorial qualities, historian Achim Landwehr emphasized a constellation of multiple times rather than promoting a linear understanding of time. Doing so, he drew attention to the fact that linear understandings and narrations of history are based on cultural techniques; narration, including that of events, often takes place through the medium of text and thus, according to Landwehr, within a linear, successive form.$^{37} \mathrm{He}$ also described relations among past, present, and future as "chronoferences" (Chronoferenzen), or as produced connections and combinations. In doing so, he rejected linear, homogeneous notions of temporality and instead advocated focusing on the created variable relations: "And this rethinking should not take place in a dualistic sense, but rather as an examination of the possibility of chronoferences as a linkage of present and absent times." 38

It is no accident that Landwehr called these temporal relations "timescapes" (Zeitschaft), referring to the word "landscape" (Landschaft), which also designates a specific pictorial genre. ${ }^{39}$ Just as one sees relations between different levels and elements in the pictorial plane of a painted landscape, Landwehr saw different temporal dimensions as being brought together in a specific relation. Contrary to linear understandings of time (and the associated notion of the event as a homogeneous temporal unit), Landwehr contested separations of past and present and instead focused on the intrarelation of different times to one another in historical narrations as well as in our every day lives. ${ }^{40}$ In the same sense that Boehm argued that different temporal elements come together within the unity of picture, Landwehr claimed that within, for example, a historical narration different temporal dimensions are

35. Ibid., 120-21.

36. Walter Benjamin, The Arcades Project, transl. Howard Eiland and Kevin McLaughlin (Cambridge, MA: Harvard University Press, 2002), 463.

37. Achim Landwehr, Die anwesende Abwesenheit der Vergangenheit: Essay zur Geschichtstheorie (Frankfurt: Fischer, 2016), 282.

38. Ibid., 287.

39. Ibid., 309.

40. Ibid., 313. 
connected to each other. Landwehr emphasized the mutual effects of different temporal dimensions within a relation of times as follows:

It is therefore essential to assume that every relation (of space and time or of other elements) represents an intrarelation. We are therefore dealing with a reference that not only couples two (or more) elements to one another, but also mutually changes the elements involved through the coupling. The relational betwixt is an active and productive part of this connection. ${ }^{41}$

The intrarelation highlighted here - that is, the mutual effect of a relation - is again comparable to Boehm's image theory, particularly his notion of "iconic difference" and his interpretation of the picture as an event in which relations between continuous and discrete elements occur. Boehm's definition of the picture parallels Landwehr's definition of the event as a unit where a complex relation of times becomes obvious. Hence, both time and event unite heterogeneous relations, in turn creating a historically specific relation of different temporal dimensions.

The structural similarities between the picture and the event can also be used to investigate the pictorial mediatization of the event. What stays abstract within the concept of the event - that is, the inherent relations of different times-becomes tangible within pictures depicting events. The pictorial plane unites the different temporal elements that occur in relation to each other in the event. However, it is crucial to look beyond the representational level of the picture (what is depicted) and examine the picture's "iconic difference" - that is, to regard how the relations of distinct elements in the picture contribute to the whole pictorial plane. It is also important to keep in mind not only how different iconographic traditions come together in the picture but also how genre and media conventions are negotiated within the pictorial unit. It is by attending to differences of iconographies, conventions of media and depiction, and relations among distinct elements in the pictorial plane that we can understand how different times intersect in the pictorial mediatization of the event.

\section{REINHART KOSELLECK'S APPROACH TO THE PICTORIAL TEMPORALITIES OF THE EVENT}

In his theory of historical times, Koselleck sought to understand the category of the event and its temporal complexity. ${ }^{42} \mathrm{He}$ described his theory of history (Historik) as an attempt to address the "double-sided nature of each history, encompassing both a cluster of events and its representation." ${ }^{\prime 3} \mathrm{He}$ identified events as the products of a narrative procedure, which he claimed was characterized by an inherent differentiation: "A minimum of 'before' and 'after' constitutes the significant unity that makes an event out of incidents." ${ }^{44}$ Koselleck distinguished the structure that needs to be described from the event that needs

41. Ibid., 307.

42. For more on this, see Britta Hochkirchen, "Bildzeiten des Ereignisses: Reinhart Koselleck und das fotografische Bild," Rundbrief Fotografie 26, no. 3 (2019), 25-35.

43. Reinhart Koselleck, "Historik and Hermeneutics," in Sediments of Time: On Possible Histories, transl. and ed. Sean Franzel and Stefan-Ludwig Hoffmann (Stanford: Stanford University Press, 2018), 43.

44. Koselleck, "Representation, Event, and Structure," 106. 
to be narrated, particularly in its historical representation. Based on his theory of the "sediments of time," he emphasized the "contemporaneity" of different times, which he claimed was also evident in the historical narration of events ${ }^{45} \mathrm{He}$ also noted that linguistic representations - and concepts in general- "have a different internal temporal structure than the events." ${ }^{46}$

Koselleck theorized linguistic representations of the event and their inherent temporal structures, but he also practiced drawing and photography for decades, to which the approximately thirty thousand objects in his picture collection testify. ${ }^{47}$ Within this pictorial legacy, there are numerous photographs taken by Koselleck himself as well as a collection of postcards, newspaper articles, and other pictures, which he cataloged by location and subject. ${ }^{48}$ Examining this pictorial archive with an eye toward the different motifs depicted there, one can discern evidence of not only his numerous research trips but also his thematic interests. Indeed, monuments, horses and their riders, clocks, and means of transportation of all kinds appear in many of his photographs. Koselleck's pictorial legacy (especially his photographs) complements his writings about the history and theory of historical times, and especially his scholarship on the plural temporality of the event. In clear analogy to his thinking about narrative representation, in his photography Koselleck devoted himself to pictorial representations of the event, once again focusing on temporal relations, but in this case he explored how they intersect within the limits of the pictorial plane. It is striking, though perhaps not surprising, that Koselleck also emphasized central characteristics of the picture's temporality that are congruent with Boehm's notion of "iconic difference" and Imdahl's concept of the relational quality of pictures; after all, the three knew each other through their participation in the Poetik und Hermeneutik research group. ${ }^{49}$

There are only a few explicit references to pictorial temporality in Koselleck's writings. And yet against the backdrop of his own pictorial practices, these references have a distinct heuristic value for discussions of temporality and pictorial representations of the event. A particularly notable reference to pictorial temporality can be found in the preliminary remarks of the essay "Modernity and the Planes of Historicity," which Koselleck based on his inaugural lecture

45. Reinhart Koselleck, "Einleitung," in Zeitschichten: Studien zur Historik (Frankfurt: Suhrkamp, 2015), 9 .

46. Reinhart Koselleck, "Sprachwandel und Ereignisgeschichte," in Begriffsgeschichten: Studien zur Semantik und Pragmatik der politischen und sozialen Sprache (Frankfurt: Suhrkamp, 2006), 45.

47. For Koselleck's pictorial legacy, see "Bildnachlass Reinhart Koselleck," Deutsches Dokumentationszentrum für Kunstgeschichte - Bildarchiv Foto Marburg, accessed 7 February 2020, https://www.uni-marburg.de/de/fotomarburg/bestaende/uebernahmen/koselleck. For more on Koselleck's practical and theoretical engagement with pictures, see Reinhart Koselleck und die Politische Ikonologie, ed. Hubert Locher and Adriana Markantonatos (Berlin: Deutscher Kunstverlag, 2013); and the essays published in Forum Interdisziplinäre Begriffsgeschichte 7, no. 1 (2018), https://www.zfl-berlin.org/files/zfl/downloads/publikationen/forum_begriffsgeschichte/ ZfL_FIB_7_2018_1.pdf. For an overview of Koselleck's work on and with images, see Adriana Markantonatos, "Geschichtsdenken zwischen Bild und Text: Reinhart Kosellecks 'Suche nach dem (. . .) Unsichtbaren"” (PhD diss., Philipps-Universität Marburg, 2018).

48. Adriana Markantonatos, "Eine Fotohexerei: Einblicke in Reinhart Kosellecks Bildarchiv," in Zettelkästen: Maschinen der Phantasie, ed. Heike Gfrereis and Ellen Strittmatter (Marbach: Deutsche Schillergesellschaft, 2013), 69.

49. For an examination of these intellectual connections and influences, see Markantonatos, "Geschichtsdenken zwischen Bild und Text," 213-57. See also Markantonatos, "Absatteln der 'Sattelzeit'?" 79. 
at Heidelberg University in 1965. Koselleck opened and closed this essay with discussions of Albrecht Altdorfer's 1529 painting, The Battle of Alexander at Issus, which depicts the event of the Battle of Issus in $333 \mathrm{BC}$ (see figure 1)..$^{50}$ Koselleck began his discussion of the painting by first highlighting some of its individual aspects before emphasizing two anachronisms contained within it. In discussing the first anachronism, Koselleck pointed out that Altdorfer chose to convey each army's size, including the number of fallen soldiers, on a plaque positioned in the sky at the top of the painting; the fallen soldiers, however, are still shown to be alive in the painting. ${ }^{51}$ The second anachronism Koselleck highlighted relates directly to his famous thesis of a beginning "temporalization (Verzeitlichung) of history" between 1500 and 1800 that he claimed concluded with "the peculiar form of acceleration which characterizes modernity." 52 With this thesis in mind, Koselleck identified a peculiar mixture of historical references - indeed, of times - depicted in Altdorfer's painting: "From their feet to their turbans, most of the Persians resemble the Turks who, in the same year the picture was painted (1529), unsuccessfully laid siege to Vienna." ${ }^{53}$ As Koselleck thus pointed out, the title of Altdorfer's painting suggests that it depicts events from $333 \mathrm{BC}$, but the painting's details (particularly the costumes worn by the soldiers) refer to events that took place in 1529.

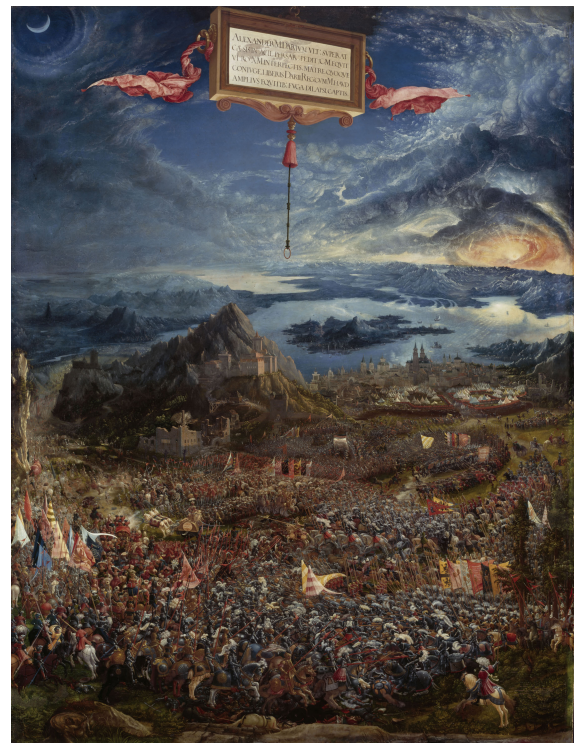

Fig. 1: Albrecht Altdorfer, The Battle of Alexander at Issus, 1529, oil on wood, 158 x 120 $\mathrm{cm}$, Munich, Alte Pinakothek. (C) bpk I Bayerische Staatsgemäldesammlungen. Used with permission.

50. For more on Koselleck's discussion on Altdorfer's painting, see Hubert Locher, "Denken in Bildern: Reinhart Kosellecks Programm Zur politischen Ikonologie," in Locher and Markantonatos, Reinhart Koselleck und die Politische Ikonologie, especially 297-98.

51. Koselleck elaborated on these points in "Modernity and the Planes of Historicity," in Futures Past, 9-25, especially 9-10.

52. Ibid., 11.

53. Ibid., 10 
Koselleck used his observations about the amalgamation of different times (333 BC and 1529) in one pictorial mediatization of the event (The Battle of Alexander at Issus) to discuss the unified, shared historical experience of premodern times: "The event that Altdorfer captured was for him at once historical and contemporary.... The present and the past were enclosed within a common historical plane." ${ }^{54}$ According to Koselleck, it was three centuries later, around 1800, that Friedrich Schlegel finally possessed "critical-historical distance with respect to Altdorfer's masterpiece," as he was able to differentiate between his own society's perception of time and the way time operates in the version of antiquity that Altdorfer's painting depicts. ${ }^{55}$ Indeed, history itself had taken on a different quality at this juncture around 1800 , as it was now experienced as temporalized. Koselleck explained: "For [Schlegel], history had in this way gained a specifically temporal dimension, which is clearly absent for Altdorfer." ${ }^{56}$

But what do Koselleck's insights reveal about the temporality of the historical event in its pictorial mediatization? He indeed used this discussion of Altdorfer's painting as a way to interpret pictorial temporality. The crucial point, however, is that he drew conclusions from the lack of distinctions traced between different historical moments - or, rather, from the amalgamation of times - in this painting in order to discuss premodern understandings of time and history. For Koselleck, it is through the painting's anachronisms that Altdorfer displays a premodern understanding of history as a common space of experience. Koselleck thus saw the interplay of different times in pictorial representations of events as an opportunity to gain insights into certain historical understandings of time and history.

In the context of what he conceived of as a temporalized and accelerated modernity and its picture production, Koselleck was particularly interested in the medium of caricature and the predicted acceleration of modernity that caricatures often depicted. He was especially interested in caricatures by Honoré Daumier, who depicted nineteenth-century political events such as the Revolution of 1830 in France. In contrast to the amalgamation of historical moments depicted in Altdorfer's The Battle of Alexander at Issus, Daumier's caricatures highlight inherent differences between historical moments. In his essay "Daumier and Death," Koselleck identified the marking of different temporalities as a peculiar feature of Daumier's “modern" caricatures. He explained that, in Daumier's caricatures, "the principle of composition consists of placing signals of reality and newly created or old allegories together in such a way that the unity of the picture thematizes the difference in any particular case." ${ }^{57}$

Koselleck noted that Daumier combined two different modes of depiction within one caricature. On the one hand, Daumier included "newly created or old allegories," including symbols meant to represent death. On the other hand, Daumier contrasted these symbols with pictorial elements that were related to contemporary historical events like the Revolution of 1830 in France. Koselleck

54. Ibid.

55. Ibid.

56. Ibid.

57. Reinhart Koselleck, "Daumier and Death," in The Practice of Conceptual History: Timing History, Spacing Concepts, transl. Todd Samuel Presner et al. (Stanford: Stanford University Press, 2002), 277. 
interpreted these two representational techniques as evidence that the transformation of an occurrence into an event depends on the repetition of structures (such as themes or symbols). ${ }^{58}$ This combination of commonly used, and thus historically nonspecific, pictorial modes with imagery that refers to specific contemporary events becomes evident in the limited area of the pictorial plane. By positioning these distinct pictorial times alongside one another within the picture's unity, Daumier displayed a modern - that is, a temporalized - understanding of history. Koselleck explained: "What appears aesthetically reconciled is precisely what is thereby thematized as difference-difference that can be caricatured." 59

Koselleck was interested in visual representations of the event because he believed that relations between different times were worked out anew in the medium of the picture. He thought that the ways in which different times are set in relation to one another in pictorial spaces offers insight into not only the complex interplay of times that are characteristic of the event but also the specific historical quality of modern time. Looking at the way Koselleck responded to inherent pictorial differences reveals similarities between his approach to the pictorial mediatization of the event and Gottfried Boehm's image theory, which used the "iconic difference" to justify the temporal nature of the picture and emphasized the quality of the picture as a structure of relations. What according to Boehm is a general characteristic of pictures is used by Koselleck as the empirical basis for his observations about the relations between different times and events. Here again, it is the picture that creates the unifying frame through which contrasts between different times (and therefore specific historical relations of those different times) become visible.

Koselleck's own photography also shows how he himself produced or even variegated pictorial relations of different times, particularly with regard to the event. Throughout his career, he linked the "synchronization" or "convergence" of event and picture to the modern media of photography and television. ${ }^{60} \mathrm{In}$ many of his photographs showing media events, he used the pictorial medium to promote critical and temporal distance from the actual event, which seemed to be neutralized through mediatization (almost like Altdorfer's The Battle of Alexander at Issus). In this way, Koselleck's photographs of television broadcasts of events are particularly striking. He regularly photographed media events, including a 2002 television broadcast of All the Queen's Horses (see figure 2 a-d). ${ }^{61}$ Koselleck's photographs of All the Queen's Horses are blurry and dark, and they show little color contrast. In fact, the actual event - that is, the horse show - is hardly recognizable. It is clear that, in taking these photographs, Koselleck was not concerned with aesthetic value or with providing a clear,

58. For an extended discussion of this, see Reinhart Koselleck, "Sediments of Time," in Franzel and Hoffmann, Sediments of Time, 3-9, especially 5.

59. Koselleck, "Daumier and Death," 270.

60. Reinhart Koselleck, "Der Aufbruch in die Moderne oder das Ende des Pferdezeitalters," in Historikerpreis der Stadt Münster: Die Preisträger und Laudatoren von 1981 bis 2003, ed. Berthold Tillmann (Münster: LIT, 2005), 170; Koselleck, "Daumier and Death," 267.

61. Digital archive of Reinhart Koselleck's photographs of All the Queen's Horses, 2002, inventory number 047-11-0160, Bildnachlass Reinhart Koselleck, Deutsches Dokumentationszentrum für Kunstgeschichte - Bildarchiv Foto Marburg, Marburg, https://www.bildindex.de/document/ que20171721. 
unambiguous depiction of the event. Rather, the photographs testify to his interest in the picture's capacity to show the relations of different times in an event. He archived these photographs and sorted them under the category "Horsemen Generalia-Folklore." ${ }^{2}$ As he often did, Koselleck took numerous (in this case, seventeen) photographs of the event, thus separating the show's continuous narrative into a sequence of individual pictures. In addition, he chose different moments in this event to photograph and adopted different visual perspectives on the motif of this event. Ten photographs show the full television set and picture; the other seven photographs depict only the actual television screen. The fact that Koselleck also included the television set as a frame within some of his photographs once again emphasizes his awareness of the inner relationality of different modes of representation: the show, the medium, and the photographer's space relate to each other within the unity of the photograph, in turn referring to and presenting different times of this event. By combining these various pictorial elements, Koselleck marked temporal distinctions in the picture itself. In this way, he broke with the specific temporal quality of "simultaneity" of television or film that complicates the critical distancing from what is seen ${ }^{63}$ However, a temporally homogeneous, perhaps even simultaneous, picture would preclude such knowledge about the different temporal dimensions that determine an event.

Especially with regard to the horses, the constellation of different times was of great interest to Koselleck, since he spoke of the historical possibility of periodization in a pre-horse, horse, and post-horse age. In modern times, he stressed, the horse had lost its dominant position in society with changes in locomotion, the economy, and power relations; but it had returned, albeit under modern circumstances, to the leisure sector as a symbol of power ${ }^{64}$ Koselleck's photographs of the televised horse parade depict the military costumes of the horse riders as well as Queen Elizabeth. The different layers of time from past, present, and future are clarified through their photographic relation. In alternating photographic positions and perspectives on his subject matter, Koselleck also emphasized the temporality of his own gaze, thus bringing his own presence into the temporal relation of the photograph. In this way, he once again embedded his pictorial pratice in his theory of history, in which the temporality of every historical finding formed an important premise: "All historical knowledge is locationally determined and hence relative. Aware of this, history allows itself to be assimilated critically-verstehend, leading in turn to true historical statement." 65 With the constant variations in his photographic position and perspective on the horse parade, Koselleck ensured that the temporal relations of the event also are reflected in its visual representation. ${ }^{66}$

62. Ibid.

63. Koselleck himself explained this point: "The film, being temporally constricted, puts the observer under heightened pressure of sensory internalization" ("Der Film, zeitlich determiniert, setzt den Betrachter unter einen erhöhten Druck sinnlicher Internalisierung") ("Politische Sinnlichkeit und mancherlei Künste," in Politische Inszenierung im 20. Jahrhundert: Zur Sinnlichkeit der Macht, ed. Sabine R. Arnold, Christian Fuhrmeister, and Dietmar Schiller [Wien: Böhlau, 1998], 27).

64. See Koselleck, "Der Aufbruch in die Moderne oder das Ende des Pferdezeitalters," 168.

65. Reinhart Koselleck, "Perspective and Temporality: A Contribution to the Historiographical Exposure of the Historical World," in Futures Past, 129-30.

66. For more on this, see Peter Geimer, "Photography as a 'Space of Experience': On the Retrospective Legibility of Historic Photographs," Getty Research Journal 7 (2015), 97-108. 

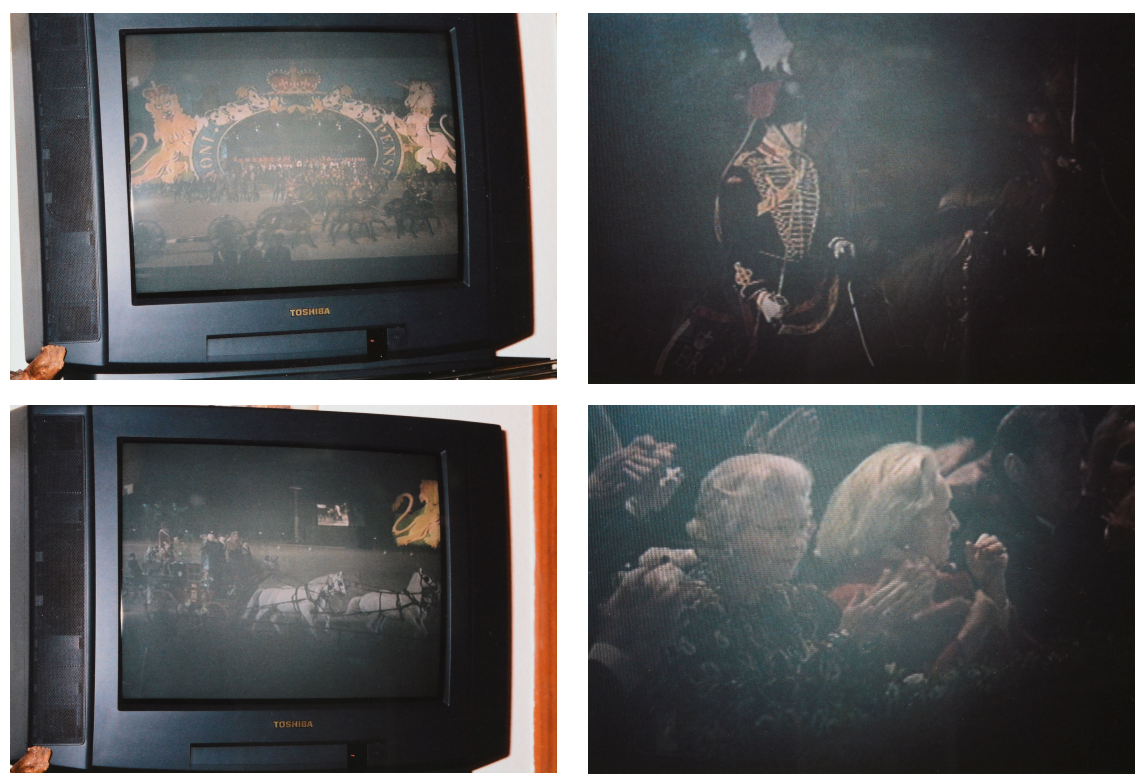

Fig. 2 a-d: Reinhart Koselleck, 4 of 17 photographs of the television show All the Queen's Horses, 2002, Deutsches Dokumentationszentrum für Kunstgeschichte - Bildarchiv Foto Marburg. (C) Bildarchiv Foto Marburg/Reinhart Koselleck. Used with the kind permission of Reinhart Koselleck's community of heirs.

Long before Landwehr called for an investigation of chronoferences, such as the relations of present and nonpresent times, Koselleck had already made the relational nature of pictorial temporality visible in his pictorial practices.$^{67}$ For the historical concept of the event in particular, Koselleck's aim was to use the pictorial representation of the event to interweave different times and temporal modes within the spatial unity of the picture. The ways in which such temporal differences enter into the pictorial mediatization of an event and relate to one another (or are assimilated together, as shown in Koselleck's examination of Altdorfer's painting) provides insight into the different temporal dimensions of the event. Koselleck emphasized the immanent contrast of different times, which come together within the pictorial unit in the form of the image's different visual elements and deployed genre conventions. He was interested in not only the inherent pictorial negotiations between the time dimensions of repetitive structures and change but also the temporality between the event in actu and its perception through mediatization. Last but not least, examining the pictorial mediation of the event, as Koselleck demonstrated with his own photographic practices, shows that its temporal relation can always be renegotiated.

\section{PICTORIAL TEMPORALITY AND THE RELATIONAL TIME OF THE EVENT}

Pictures are often used to gain insight into historical events, but we rarely consider the extent to which the picture structures the temporality of the event. This

67. For Landwehr's critique of Koselleck's theory of time, see Achim Landwehr, "Von der 'Gleichzeitigkeit des Ungleichzeitigen,"” Historische Zeitschrift 295, no. 1 (2012), 1-34, especially 19-20. 
article has shown that time is not an external dimension that is merely represented in the picture. On the contrary, building on Boehm's image theory, I have shown that the picture also possesses a specific temporal quality that is based on the inherent "iconic differences" of contrasting pictorial elements. The relations between different elements in a picture generate a specific pictorial temporality, which in turn structures the temporality of the mediated event.

In this way, it becomes clear that we can use pictures to examine-and even produce-specific relations between different times of events. In its second section, this article sketched how Koselleck dealt with pictorial temporality in both his scholarship on the theory of history and his own photography. I have shown that his engagement with various pictorial modes - paintings, caricatures, and photography-enabled him to theorize how pictures put different times in relation to each other or, on the contrary, how they visually undermine the differences of various times. In his own photography, Koselleck tested the relation and differentiation of various times, and he often did so in ways that allowed him to call attention to and scrutinize his own presence as a photographer and a historian. Hence, Koselleck used his considerations of pictorial temporality to draw conclusions about not only temporal (re)constructions of events but also social understandings of time and history.

In order for a reconceptualization of the category of the event as a temporal focal point to be fruitful, it is necessary that we consider how pictorial mediations of the event depict its distinctive temporalities. To put it bluntly, pictures are, in many cases, the sites where specific temporal relations are realized and marked. Hence, studying pictures can offer helpful insights into questions highlighted by scholarship on the theory of history. As Koselleck has demonstrated, pictures should not only be regarded as mere depictions of events. Indeed, they are more than the motifs they depict and should therefore be understood as relational arrangements in which different modes and temporal dimensions interact with one another. Pictures therefore play a central part in the relational timing of events. The project of connecting the picture's temporal dimensions with the insights of theories of history is still in its early stages, waiting for future events.

\section{Bielefeld University}

